\title{
THE ESTIMATION OF THE REGIMEN AND FORMER FIRN LIMIT OF A GLACIER
}

\author{
By J. H. Mercer \\ (Red Hone Cottage, Urchfont, Wiltshire)*
}

\begin{abstract}
An account is given of how, when accurate topographic maps of a glacier are available, not only the regimen but also the probable response to a change in the firn limit can be calculated from the area distribution. The derivation of the formula used is explained and an account given of its application in suitable areas of Alaska, where recent climatic changes are discussed.

RÉsumÉ. L'auteur explique comment il est possible de calculer à partir de la distribution des surfaces, lorsque des cartes topographiques précises sont disponsibles, non seulement le régime d'un glacier mais aussi la réponse probable à une variation d'altitude de la ligne de névé. L'élaboration de la formule utilisée est explicitée ainsi que son application à des zones propices de l'Alaska pour lesquelles des récentes variations climatiques sont discutées.

Zusammenfassung. Unter der Voraussetzung, dass für einen Gletscher genaue topographische Karten vorliegen, wird eine Methode entwickelt, die nicht nur den Haushalt sondern auch die wahrscheinlichen Folgen einer vertikalen Verlagerung der Firnlinie aus der Flächenverteilung zu berechnen gestattet. Es wird die Ableitung der benutzten Formel erläutert und über ihre Anwendung in geeigneten Gebieten Alaskas berichtet, die dort jüngere Klimaänderungen zu diskutieren gestattet.
\end{abstract}

THE ratio of the accumulation area to the total, used as an indication of a glacier's regimen, is unsatisfactory because the different rates of increase of net ablation below, and of net accumulation above, the firn limit are ignored. When the area distribution and the firn limit of a glacier are known, a formula can be used that not only calculates a glacier's condition much more accurately, but also indicates its probable response to a change in the firn limit.

On the Gorner Gletscher in Switzerland and the Taku Glacier in Alaska, the increase in net ablation below the firn limit has been found to be almost linear with altitude. ${ }^{\mathrm{I},}{ }^{2}$ Thus, if the ablation area is divided into equal vertical intervals, the net ablation in each is in the ratio I : $3: 5: 7: 9$ and so on. Above the firn limit, the increase in net accumulation is also approximately linear, except within about $500 \mathrm{ft}$. ( $\left(5^{2} \mathrm{~m}\right.$.) of the firn limit, where the rate of increase is greater due to changes in the albedo of the surface in this zone, and at higher elevations where, as the zone of maximum snowfall is approached, the rate of increase begins to fall. ${ }^{2,} 3$ It appears that, if the net accumulation from the firn limit to $500 \mathrm{ft}$. (I $52 \mathrm{~m}$.) above is taken as 2 , the values for successive $500-\mathrm{ft}$. ( $152 \mathrm{~m}$.) intervals are in the ratio $5: 7: 9:$ I I and so on until the zone of maximum snowfall is approached. On the Juneau Ice Field the curve begins to flatten at about $5,000 \mathrm{ft}$. ( $1,524 \mathrm{~m}$.). This implies a doubling of the net accumulation between $500 \mathrm{ft}$. ( $152 \mathrm{~m}$.) and $\mathrm{r}, 500 \mathrm{ft}$. (457 m.) and a further doubling by $3,500 \mathrm{ft}$. ( $\mathrm{r}, 067 \mathrm{~m}$.) above the firn limit.

If the areas of equal vertical intervals are measured they can be multiplied by the relevant factors, but the totals for the ablation and accumulation areas will then be in different units. If the glacier is known to be in equilibrium, these two totals will be equivalent, and a factor can be found to make them equal. The same factor can be applied to glaciers not in equilibrium; the ratio of accumulation units to total expressed as a percentage will then be 50 for a glacier in equilibrium, over $5^{\circ}$ for an advancing and under $5^{\circ}$ for a receding glacier; this figure may be called the Mass Balance Index (M.B.I.). Needless to say, this is still not a precise formula; for instance, neither orientation nor the effects of wind drift are taken into account. Furthermore, no account is taken of the protective effect of surface moraine in the ablation area: this can be such a serious source of error that some glaciers are not suitable for study by this method. Above a certain level (about 5,500 ft. ( $1,676 \mathrm{~m}$.) in coastal Alaska) the net accumulation increases more and more slowly until, when the zone of maximum snowfall is

* This paper was written while the author was carrying out research at the American Geographical Society, New York. Ed. 
passed, it starts to decrease. Until the form of this curve is known, it is not possible to use the formula for glaciers with névés above this level unless only small areas are involved.

Reversing the procedure, the firn limit when a glacier was larger than at present may be determined, provided the former extent and surface level are known. Where the former extent is not known, it can be calculated by using the firn limit derived from a glacier nearby.

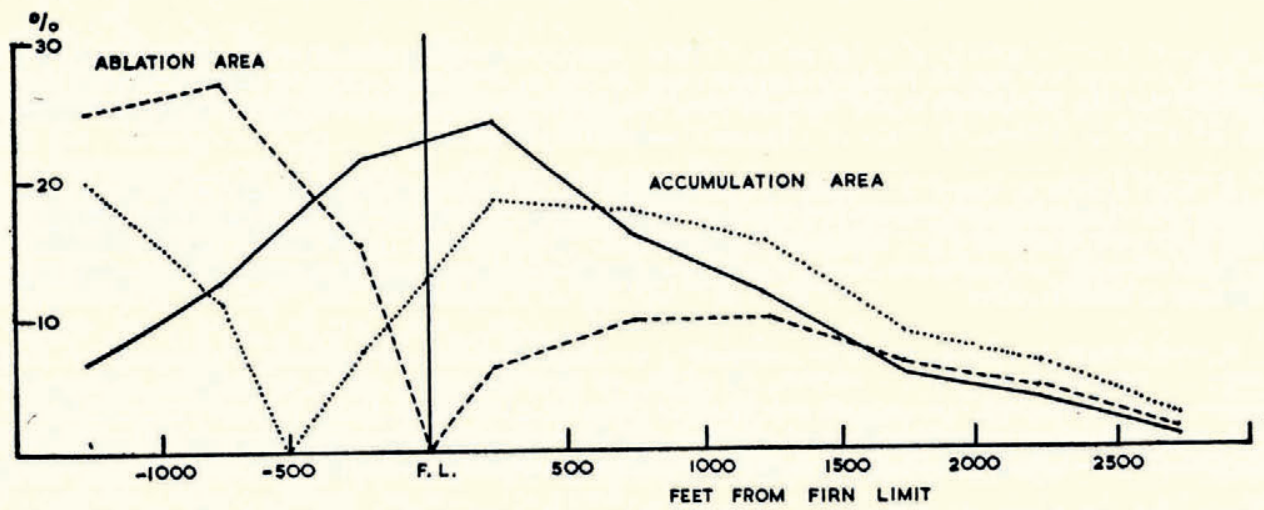

Fig. I. The area distribution and turnover distribution of the Tebenkov Glacier. Mass Balance Index: 4o, Mass Balance Index if firn limit fell $500 \mathrm{ft}$. ( $152 \mathrm{~m}$.): 70 . Percentage of total area

Percentage of total turnover if firn limit fell $500 \mathrm{ft}$. $(152 \mathrm{~m}.) \ldots \ldots$

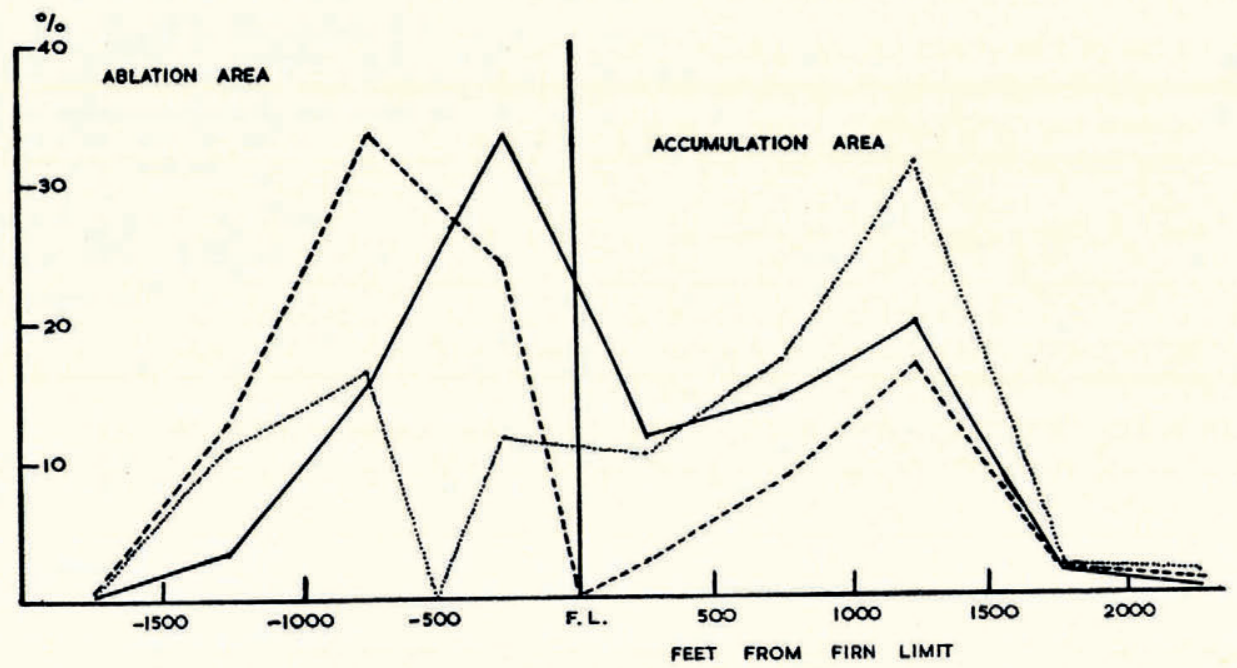

Fig. 2. The area distribution and turnover distribution of the Princeton Glacier. Mass Balance Index: 30 , Mass Balance Index if firn limit fell $500 \mathrm{ft}$. ( $152 \mathrm{~m}$.): 71 . Percentage of total area - Percentage of total turnover - - - Percentage of total turnover if firn limit fell $500 \mathrm{ft}$. $\left(\mathrm{I}_{52} \mathrm{~m}\right.$.) . . . .

The area distribution of a glacier may be plotted graphically, and the altitude of the firn limit shown. On the same graph, using different units on the vertical scale, the total net ablation and accumulation in each altitude interval may be shown. This is much more informative than the area distribution curve: it shows directly the relationship between the accumulation and ablation, shows up the comparative unimportance of areas near the firn limit (Figs. I and 2), and illustrates much more clearly the effect on the economy of changes in the firn limit (Figs. $\mathrm{I}-3$ ). 


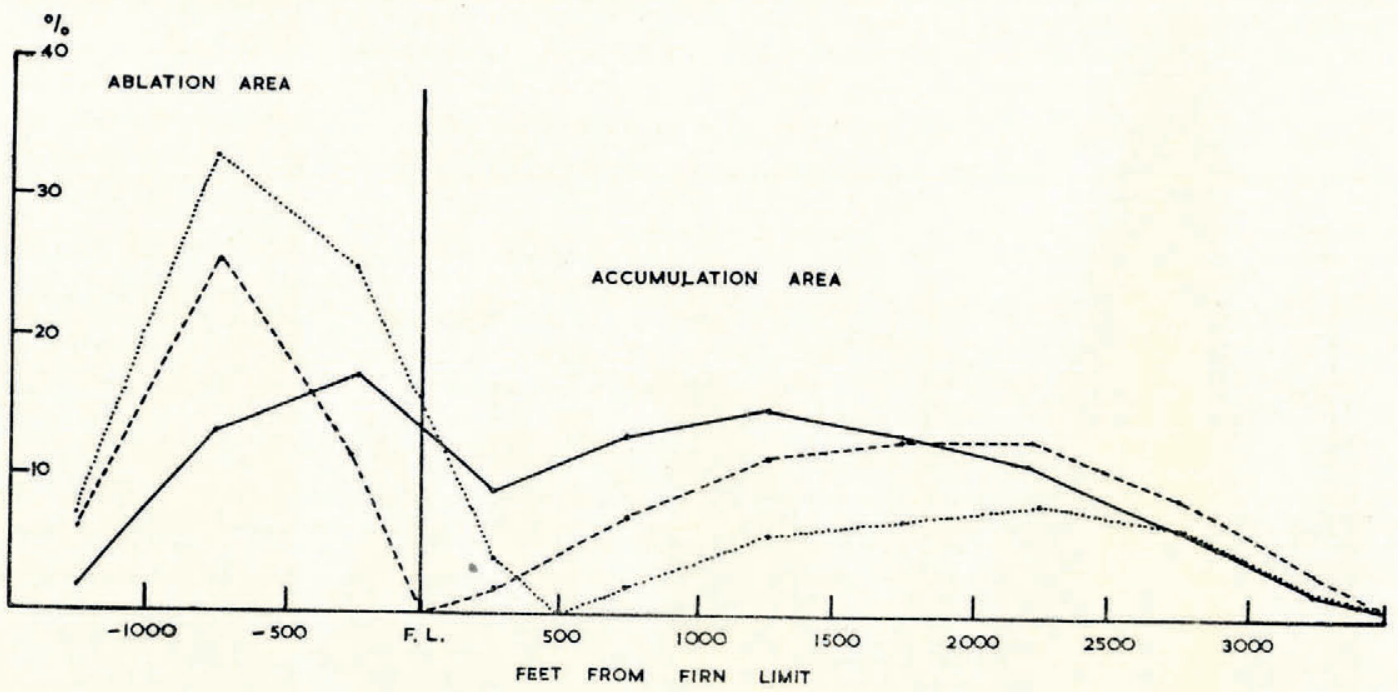

Fig. 3. The area distribution and turnover distribution of the Harriman Glacier. Mass Balance Index: 57, Mass Balance Index if firn limit rose $500 \mathrm{ft}$. $(152 \mathrm{~m}):$.31 . Percentage of total area - . Percentage of total turnover $-\ldots$ Percentage of total turnover if firn limit rose $500 \mathrm{ft}$. $\left(\mathrm{I}_{52} \mathrm{~m}\right.$.) . . . . .

\section{The Application of the Formula in a Test Area}

The region chosen to apply the theory was the Kenai Peninsula on the west side of Prince William Sound in Alaska (Fig. 4), for the following reasons:

(i) There are large-scale contoured maps, and air photographs for determining firn limits.

(ii) Advancing, stable and receding glaciers are all present.

(iii) Maximum heights are probably below the zone of maximum snowfall.

Areas were measured in vertical intervals of $500 \mathrm{ft}$. ( $152 \mathrm{~m}$.); the accuracy of the method does not merit smaller intervals. With glaciers thought to be approximately in equilibrium, a divisor of 6 was found to reduce the figures for the accumulation area to those of the ablation area. This implies, for instance, that the net ablation per unit area between 500 and $\mathrm{r}, 000 \mathrm{ft}$.

Table I. Method of Calculation of the Mass Balance Index

\begin{tabular}{|c|c|c|c|c|c|c|c|c|}
\hline \multirow{2}{*}{\multicolumn{2}{|c|}{$\begin{array}{l}\text { Distance from } \\
\text { firn limit } \\
\text { (ft.) }\end{array}$}} & \multicolumn{6}{|c|}{ Example: Harriman Glacier } & \multirow[b]{2}{*}{$\begin{array}{c}\text { per cent } \\
\text { of total } \\
(M . B . I .)\end{array}$} \\
\hline & & $\begin{array}{c}\text { per cent } \\
\text { of } \\
\text { area }\end{array}$ & $\begin{array}{c}\text { multiply } \\
\text { by }\end{array}$ & equals & $\begin{array}{c}\text { divide } \\
\text { by }\end{array}$ & equals & total & \\
\hline \multicolumn{2}{|c|}{ 1000-I50o below } & 2 & 5 & Io & & & & \\
\hline $500-1000$ & , & I3 & 3 & 39 & & & 66 & \\
\hline $0-500$ & ", & 17 & I & 17 & & & & \\
\hline \multicolumn{2}{|c|}{ o- 500 above } & 8 & 2 & 16 & 6 & 3.0 & \multirow{8}{*}{88} & \multirow{8}{*}{57} \\
\hline $500-1000$ & , & I3 & 5 & 65 & 6 & II 10 & & \\
\hline $1000-1500$ & ", & I5 & 7 & 105 & 6 & $17 \cdot 5$ & & \\
\hline $1500-2000$ & ", & I3 & 9 & 117 & 6 & 19.5 & & \\
\hline $2000-2500$ & ", & I I & I I & 121 & 6 & $20 \cdot 0$ & & \\
\hline $2500-3000$ & , & 6 & 13 & 78 & 6 & 13.0 & & \\
\hline \multirow[t]{2}{*}{$3000-3500$} & ", & 2 & I5 & 30 & 6 & $5 \cdot 0$ & & \\
\hline & & 100 & & & & & & \\
\hline
\end{tabular}



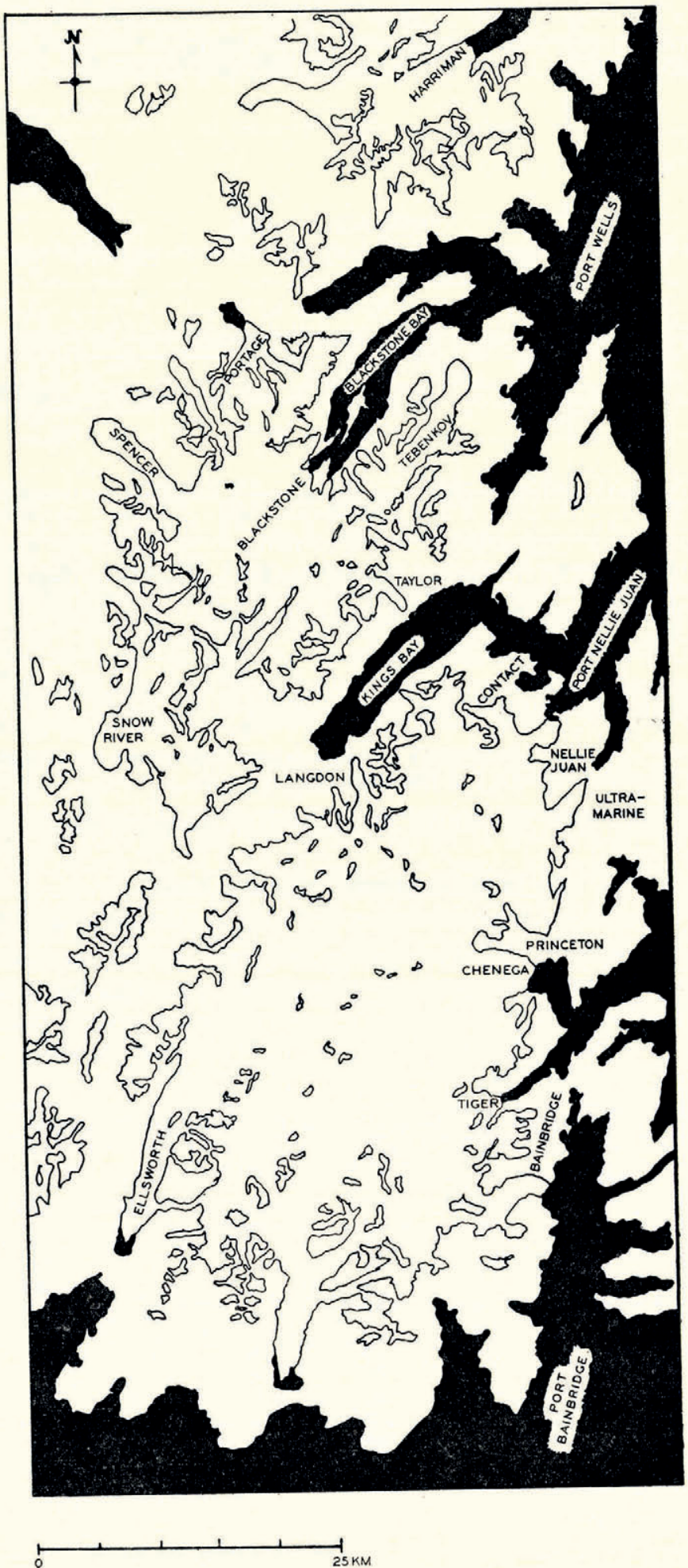

Fig. 4. Map of the Sargent and adjacent unnamed ice fields 
( 152 and $305 \mathrm{~m}$.) below the firn limit is equal to the net accumulation between $3,75^{\circ}$ and 4,250 ft. (I,I43 and I,295 m.) above.

Since air photographs are not usually taken with the prime object of showing the firn limit, they usually show only the temporary firn line. In a normal year the firn line reaches the firn limit about the beginning of September so that when photographs were taken earlier in the summer it is necessary to extrapolate. For example, the firn lines obtained from air photographs taken on 7 and I I August $195^{\circ}$ on the west side of Prince William Sound give all the glaciers - receding, stable and advancing - an excessively high Mass Balance Index. By setting the firn limit $250 \mathrm{ft}$. ( $76 \mathrm{~m}$.) higher - reasonable for a further 3 to 4 weeks ablation - more reasonable figures are obtained.

Table II. Mass Balance Indices of Glaciers in the Test Area

$\begin{array}{lccc}\text { Glacier } & \begin{array}{c}\text { Unadjusted } \\ \text { M.B.I. }\end{array} & \begin{array}{c}\text { Adjusted } \\ \text { M.B.I. }\end{array} & \text { Condition } \\ \text { Snow River } & 85 & 70 & \text { Advancing (probably) } \\ \text { Harriman } & 75 & 57 & \text { Advancing } \\ \text { Portage } & 58 & 48 & \text { Slow shrinkage } \\ \text { Spencer } & 54 & 43 & \text { ", ”, } \\ \text { Bainbridge } & 54 & 43 & \text { ”, } \\ \text { Taylor } & 52 & 40 & \text { Moderate shrinkage } \\ \text { Princeton } & 43 & 29 & \end{array}$

Firn lines on the adjacent glaciers Nellie Juan, Ultramarine and Contact obtained at the same time (I2 August 1950) show firn limits of I, IOO-I,500 ft. (335-457 m.), I, 200-I, $500 \mathrm{ft}$. $(366-457 \mathrm{~m}$.$) and 950 \mathrm{ft}$. (290 m.). By adding $250 \mathrm{ft}$. to the average values of these firn lines, the altitudes of the firn limits may be estimated as $1,55^{\circ}, 1,600$ and 1,200 feet $(472,488$ and $366 \mathrm{~m}$.) respectively. These glaciers are extremely sensitive to small changes in the firn limit; their regimens are negative and on the verge of being very negative, as can be seen from Table III.

Table III. Effect of Change of Firn Limit on Mass Balance Index

\begin{tabular}{lrccc} 
& \multicolumn{4}{c}{ M.B.I. if firn limit was: } \\
Glacier & 1000 & I250 & I500 & I750 ft. \\
& 305 & $3^{81}$ & 457 & $533 \mathrm{~m}$. \\
Nellie Juan & & 60 & 43 & 20 \\
Ultramarine & & 67 & 45 & 13 \\
Contact & 95 & 15 & &
\end{tabular}

The tidewater glaciers Chenega, Blackstone and Tiger have Mass Balance Indices of 94, 85 and 78 respectively if their calving losses are ignored. Since they are in fact known to be more or less in equilibrium it can be calculated that by calving and undermelting they lose the same as they would from sea-level ablation areas of $9^{2}, \mathrm{I} 7$ and $6 \mathrm{~km} .^{2}$ respectively.

\section{The Application of the Formula Outside the Test Area}

In favourable cases the former outlines and contours of the lower parts of glaciers may be reconstructed with considerable accuracy from air photographs and maps. For practical reasons it is assumed that in the upper parts of the glaciers above the tree line and where possible above the present firn limit, the surface contours are the same as formerly: this is, of course, not strictly true, but the changes are far less than in the lower parts. ${ }^{4}$ The Childs Glacier may be taken as an example; this is an expanded foot glacier with a firn limit of about $2,000 \mathrm{ft}$. (6Io m.), and a Mass Balance Index of 46 implying very slow recession (as is the case). 
An outer moraine is not visible on the air photographs but according to Tarr and Martin 5 there were traces of one I. 5 miles $(2 \cdot 4 \mathrm{~km}$.) beyond the ice margin at that time. Calculations show that the firn limit when the moraine was formed was at about $\mathrm{I}, 000 \mathrm{ft}$. ( $305 \mathrm{~m}$.), that is, I, ooo ft. (305 m.) lower than today.

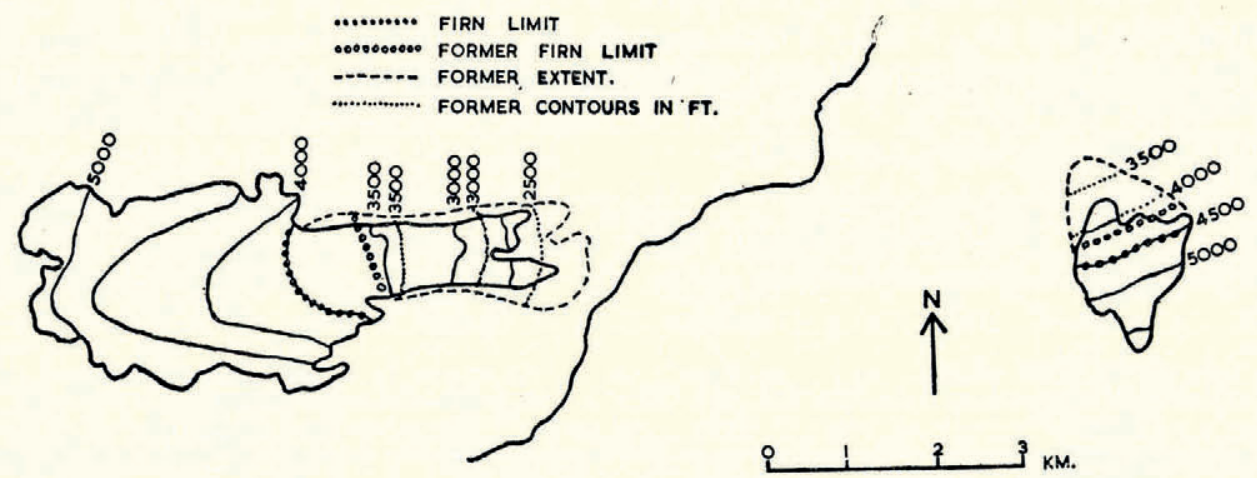

Fig. 5. Present and former extents and surface contours of the Worthington Glacier

The old moraines of the adjacent Goodwin Glacier are clearly visible on the air photographs, and the corresponding firn limit also works out at about $\mathrm{I}, 000 \mathrm{ft}$. (305 m.). The glacier today has a very heavy moraine cover, and since calculations on such a glacier give very inaccurate results, it seems that at its maximum extent the glacier must have been comparatively clean.

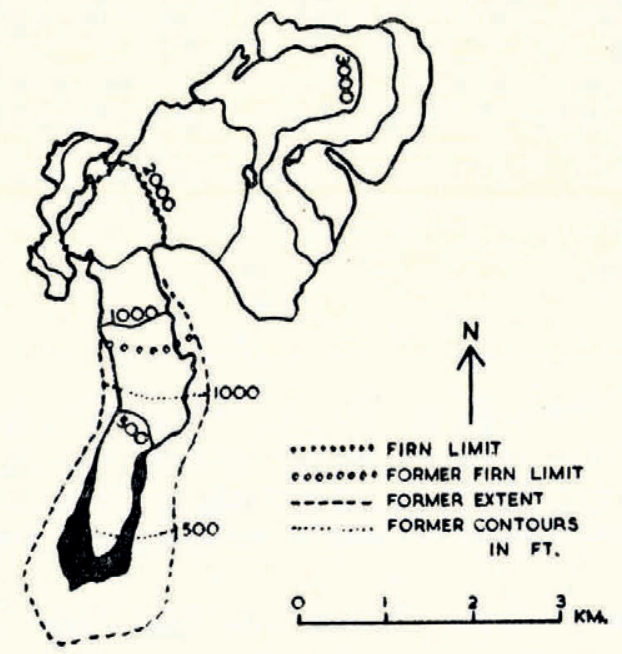

Fig. 6. Present and former extents and surface contours of the Saddlebag Glacier

Table IV shows glaciers on which calculations have been made arranged according to the rise in firn limit since the recent maximum. The Worthington, Saddlebag, Laughton and Gulkana Glaciers are shown in Figures $5^{-8 .}$ 


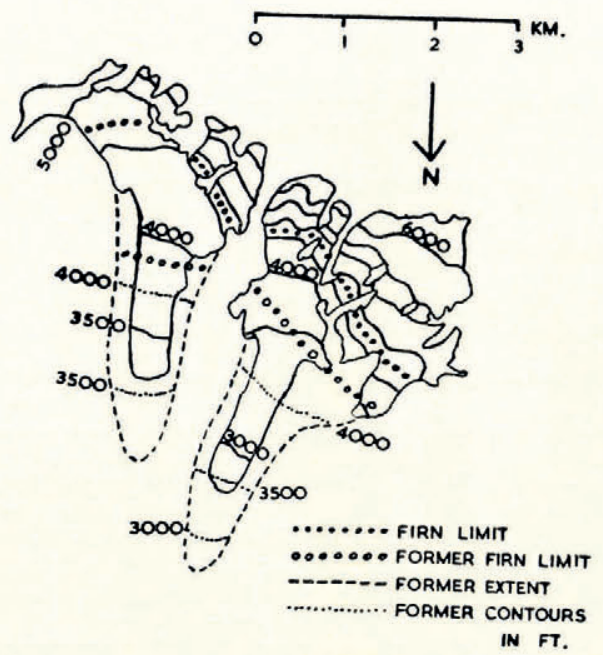

Fig. 7. Present and former extents and surface contours of the Laughton Glacier

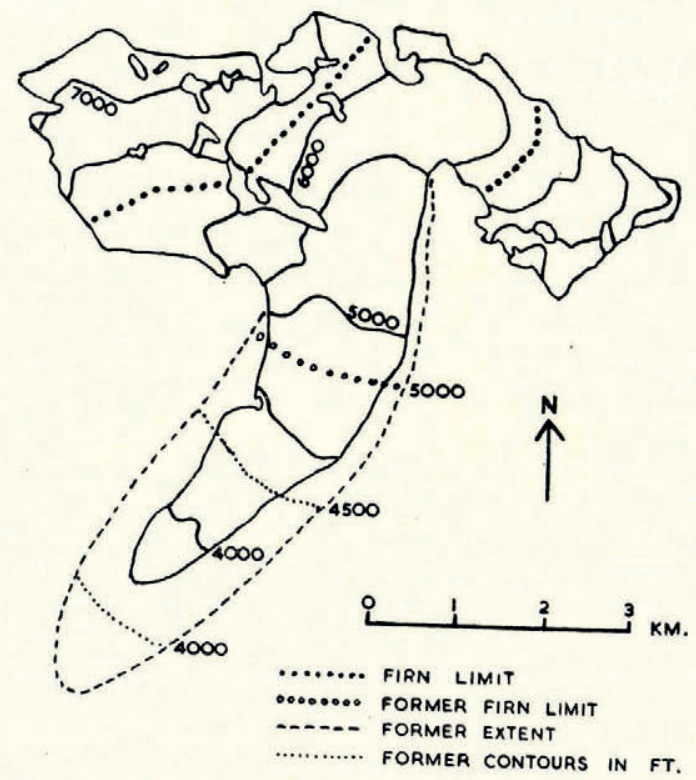

Fig. 8. Present and former extents and surface contours of the Gulkana Glacier 


\section{Table IV. Rise in Firn Limit of Glaciers}

\begin{tabular}{|c|c|c|c|c|}
\hline \multirow{2}{*}{$\begin{array}{l}\text { Glacier name } \\
\quad \text { (if any) }\end{array}$} & \multicolumn{2}{|c|}{ Position } & \multicolumn{2}{|c|}{$\begin{array}{l}\text { Rise in firn limit since } \\
\text { recent maximum }\end{array}$} \\
\hline & lat. $\mathcal{N}$. & long. $W$. & ft. & m. \\
\hline Tebenkov & $\begin{array}{l}60^{\circ} 44^{\prime} \\
60^{\circ} \mathrm{II}^{\prime}\end{array}$ & $\begin{array}{l}148^{\circ} 29^{\prime} \\
149^{\circ} \\
19^{\prime}\end{array}$ & $\begin{array}{l}250 \\
300\end{array}$ & $\begin{array}{l}7^{6} \\
9^{1}\end{array}$ \\
\hline & $60^{\circ} 05^{\prime}$ & I $49^{\circ} \mathrm{oo}^{\prime}$ & 350 & 107 \\
\hline Worthington & $\begin{array}{l}6 \mathrm{I}^{\circ} \mathrm{II}^{\prime} \\
6 \mathrm{I}^{\circ} \mathrm{II}^{\prime}\end{array}$ & $145^{\circ} 4^{\prime}$ & $\begin{array}{l}400 \\
450\end{array}$ & $\begin{array}{l}122 \\
137\end{array}$ \\
\hline & $63^{\circ} \circ 5^{\prime}$ & 1 $51^{\circ} 3^{\prime}$ & 500 & $\begin{array}{l}137 \\
152\end{array}$ \\
\hline & $63^{\circ} 04^{\prime}$ & $15^{1^{\circ}} 32^{\prime}$ & 500 & 152 \\
\hline & $5^{8^{\circ}} 43^{\prime}$ & I $34^{\circ} 47^{\prime}$, & 500 & 152 \\
\hline Saddlebag & $\begin{array}{l}59^{\circ} 32^{\prime} \\
60^{\circ} 29^{\prime}\end{array}$ & I $35^{\circ} \mathrm{O} 4^{\prime}$ & 700 & 213 \\
\hline Laughton & 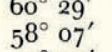 & $\begin{array}{l}145^{\circ} \\
133^{\circ} \\
17\end{array}$ & $\begin{array}{l}75^{\circ} \\
75^{\circ}\end{array}$ & $\begin{array}{l}229 \\
229\end{array}$ \\
\hline $\begin{array}{l}\text { Laughton } \\
\text { Lemon Creek }\end{array}$ & $59^{\circ} 32^{\prime}$ & $135^{\circ}$ o5, & 800 & $\begin{array}{l}22 y \\
244\end{array}$ \\
\hline & 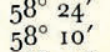 & $\begin{array}{l}\text { I } 34^{\circ} 24^{\prime} \\
\text { I } 33^{\circ} 28^{\prime}\end{array}$ & $\begin{array}{l}800 \\
800\end{array}$ & $\begin{array}{l}244 \\
244\end{array}$ \\
\hline Taku & $5^{8^{\circ}} 25^{\prime}$ & $134^{\circ} 53^{\prime}$ & $800 *$ & $244^{*}$ \\
\hline & $60^{\circ} 47^{\prime}$ & $145^{\circ}$ I $8^{\prime}$ & $85^{\circ}$ & 259 \\
\hline Bertha & $59^{\circ} 12^{\prime}$ & $135^{\circ} 39^{\prime}$ & 1000 & 305 \\
\hline Grewingk & $\begin{array}{l}59^{\circ} \mathrm{I}^{\prime} \\
59^{\circ} 37^{\prime}\end{array}$ & I $35^{\circ} 47^{\prime}$ & 1000 & 305 \\
\hline Childs & $\begin{array}{l}599^{\circ} 37 \\
60^{\circ} 40^{\prime}\end{array}$ & $\begin{array}{l}\text { I } 51^{1} 07, \\
\text { I } 44^{\circ} 45^{\prime}\end{array}$ & 1000 & 305 \\
\hline & $58^{\circ} 10^{\prime}$ & $\begin{array}{l}144 \% 45 \\
133^{\circ} 28^{\prime}\end{array}$ & $\begin{array}{l}1000 \\
1050\end{array}$ & $\begin{array}{l}305 \\
320\end{array}$ \\
\hline $\begin{array}{l}\text { Gulkana } \\
\text { Chikuminick }\end{array}$ & $63^{\circ} 14^{\prime}$ & $145^{\circ} 28^{\prime}$ & $125^{\circ}$ & $3^{81}$ \\
\hline $\begin{array}{l}\text { Chikuminick } \\
\text { Sumdum }\end{array}$ & $60^{\circ} 07^{\prime *}$ & I $59^{\circ}$ 1 $8^{\prime *}$ & 1400 & 427 \\
\hline & $57^{\circ} 4^{6^{\prime}}$ & I $33^{\circ} 28^{\prime}$ & 1500 & 457 \\
\hline
\end{tabular}

* Measured on inadequate map.

Isolines of the rise in firn limit cannot be drawn with the comparatively few results available since differences between the windward and leeward sides of individual mountain ridges confuse the overall picture. The results show, however, that the smallest rise in the firn limit $(250 \mathrm{ft} ., 76 \mathrm{~m}$.) has taken place round Prince William Sound and the largest $(\mathrm{r}, 25 \mathrm{O}-\mathrm{r}, 500 \mathrm{ft}$., $380-460 \mathrm{~m}$.) in the inland and southern coastal areas, though the rise of only $500 \mathrm{ft}$. ( $15^{2} \mathrm{~m}$.) in the Mt. McKinley area is anomalous. That the figures are of the right order of magnitude is suggested, for instance, by the observed rise of $9^{84} \mathrm{ft}$. $(300 \mathrm{~m}$.) of the firn limit in the Caucasus. ${ }^{6}$

The maximum extents may have been reached at different times during the recent period of general advance; furthermore, there is also evidence for maximum stages of the ice, in Icy and Yakutat Bays for example, many centuries ago, ${ }^{7}$ and massive terminal moraines across the mouths of many fjords must be at least as old. The maximum extent considered in this paper, however, is represented by moraines not far from the present ice fronts and usually coinciding with a still visible vegetation trimline.

\section{Recent Regords of Climatic Variation in Alaska}

Ten-year running means of ablation season temperature (May through September) and annual precipitation of some Alaskan stations since records began are shown in Figure 9. The temperature curves do not show the actual values since it is trends that are significant. The precipitation curves show the percentage deviations from "normal"; since "normal" values have been obtained from different periods of observations, the general trends at different stations are comparable, but not the steepness of the curves. The following facts emerge:

(i) Higher temperatures have been accompanied by greater precipitation except at Ketchikan where the opposite has occurred. 


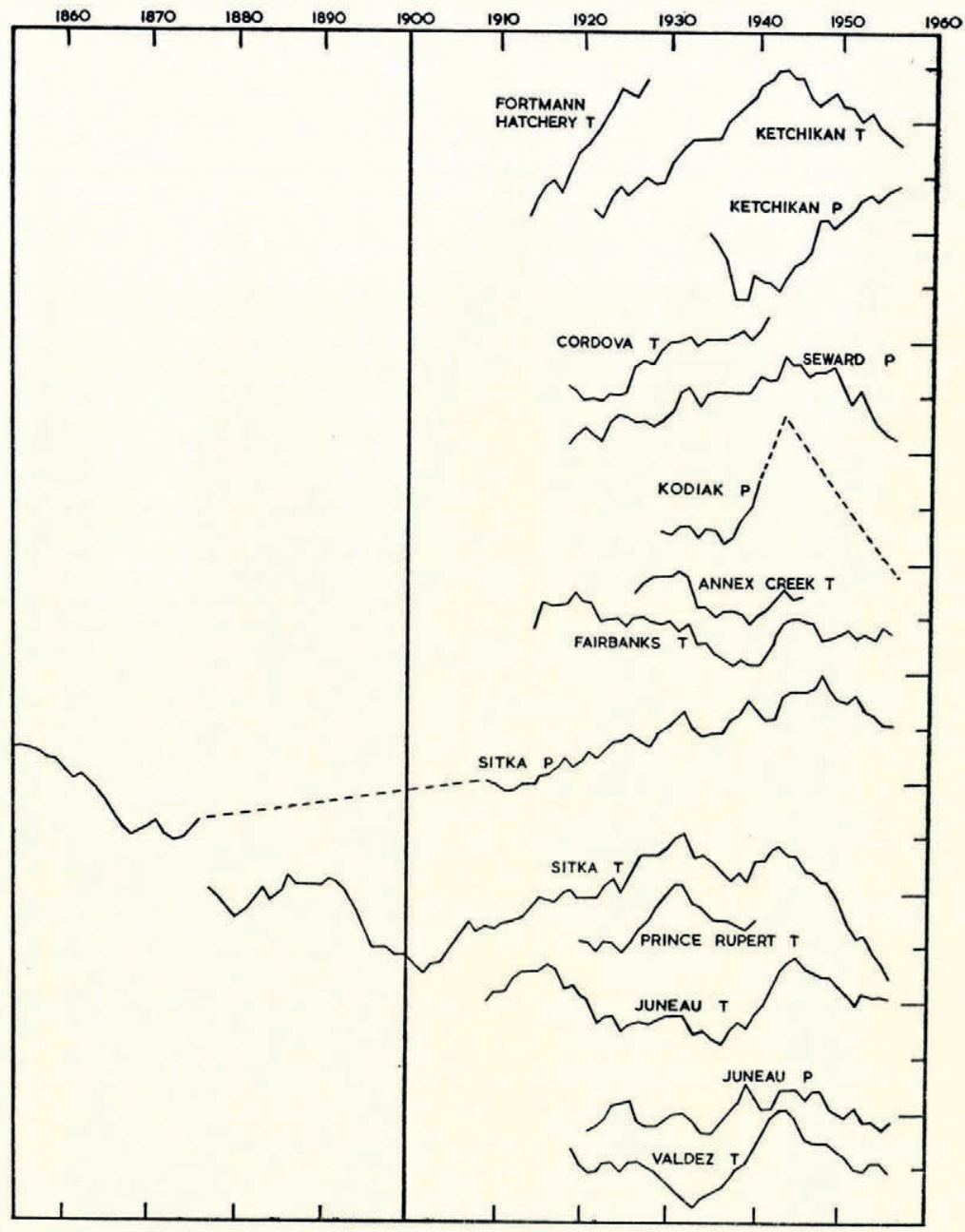

Fig. 9. Ten-year running means of ablation season temperature (April-October) and annual precipitation. Each division represents $0.5^{\circ} \mathrm{C}$. or 12.5 per cent change in precipitation. The positions of the curves on the vertical scale are arbitrary

(ii) All stations except Fairbanks show a pronounced cooling trend beginning between I 943 and 1945 . In Sitka this had amounted to $\mathrm{I} \cdot \mathrm{I}^{\circ} \mathrm{C}$. ( $2^{\circ} \mathrm{F}$.) by $195^{6 .}$

(iii) The changes most favourable to glaciers have occurred at Ketchikan in the extreme south of Alaska, where the ablation scason temperature has fallen $0 \cdot 7^{\circ} \mathrm{C}$. $\left(\mathrm{I} \cdot 2^{\circ} \mathrm{F}\right.$. $)$ and the annual precipitation increased by 24 per cent since 1943 .

MS. received 3 August 1960

\section{REFERENCES}

I. Renaud, A. Observations on the surface movement and ablation of the Gorner Glacier (Switzerland). Fournal of Glaciology, Vol. 2, No. I I, I 952, p. 54-57.

2. Nielsen, L. E. Preliminary study on the regimen and movement of the Taku Glacier, Alaska. Bulletin of the Geological Society of America, Vol. 68, No. 2, 1957, p. 17 I-8o. 
3. Ahlmann, H. W., and Thorarinsson, S. Vatnajökull. Scientific results of the Swedish-Icelandic investigations 1936-37-38. Geografiska Annaler, Årg. 20, Ht. 3-4, 1938, p. 207.

4. Ahlmann, H. W. Scientific results of the Norwegian-Swedish Spitsbergen Expedition in 1934. Part V. The Fourteenth of July Glacier. Geografiska Annaler, Arg. 17, Ht. 3-4, 1935, p. 177.

5. Tarr, R. S., and Martin, L. Alaskan glacier studies. Washington, D.C., National Geographic Society, 1914, p. 413.

6. Tsomaya B. Sh. [Change in the speed of retreat of Caucasus glaciers in connection with the warming of the climate.] Meteorologiya $i$ Gidrologiya [Meteorology and Hydrology], 1959, No. I0, p. 24-25. [Summarized in Information on Soviet Bloc International Geophysical Year Cooperation (Washington, D.C., U.S. Department of Commerce), 27 November I 959, p. 7-8.]

7. Plafker, G., and Miller, D. J. Glacial features and surficial deposits of the Malaspina district, Alaska. U.S. Geological Survey. Miscellaneous Geologic Investigations, Map I-271, 1959. 